\title{
Analisis Permintaan Cabai Merah Besar di Kota Padang, Sumatra Barat
}

\section{Analysis of Demand for Large Red Chilli in Padang City, West Sumatra}

\author{
Oleh: \\ Kurnia Hamidah', Rahmat Syahni ${ }^{2}$, Rina Sari ${ }^{2}$ \\ ${ }^{1}$ Mahasiswa Program Studi Agribisnis, Fakultas Pertanian, Universitas Andalas, Kampus Limau Manis, \\ Kecamatan pauh, Kota Padang, Sumatra Barat, Indonesia \\ ${ }^{2}$ Program Studi Agribisnis, Fakultas Pertanian, Universitas Andalas, Kampus Limau Manis, Kecamatan pauh, \\ Kota Padang, Sumatra Barat, Indonesia \\ *E-mail: kurniahamidah02@gmail.com
}

Received May 13, 2020; Revised June 23, 2020; Accepted June 30, 2020

\begin{abstract}
ABSTRAK
Penelitian ini bertujuan untuk menganalisa pengaruh dari harga cabai merah besar, harga cabai merah keriting, harga bawang merah, dan terhadap permintaan cabai merah besar di Kota Padang pada periode 2009 - 2018. Penelitian ini menggunakan data sekunder yang berbentuk time series. Metode penelitian yang digunakan adalah Analisis Linear Berganda. Variabel yang dipakai dalam penelitian ini adalah Permintaan Cabai Merah Besar di Kota Padang (Y), Harga Cabai Merah Besar (X1), Harga Cabai Merah Keriting (X2), Harga Bawang Merah (X3), serta Pendapatan Perkapita kota Padang (X4). Hasil analisis menunjukkan bahwa Harga Cabai Merah Besar, Cabai Merah Keriting, Harga Bawang Merah memiliki pengaruh yang positif dan signifikan terhadap Permintaan Cabai Merah Besar di Kota Padang namun Pendapatan Perkapita Kota Padang tidak memiliki pengaruh terhadap Permintaan Cabai Merah Besar di Kota Padang.
\end{abstract}

Kata kunci: cabai merah besar, bawang merah, permintaan, harga

\begin{abstract}
This study aims to analyze the effect of Large Red Chili Prices, Curly Red Chili Prices, Red Onion Prices, and on the Big Red Chili Demand in the City of Padang that took samples in the period 20092018. This study uses secondary data in the form of time series. The research method used is Multiple Linear Analysis. The variables used in this study are Demand for Big Red Chili in Padang City (Y), Big Red Chili Price (X1), Curly Red Chili Price (X2), Red Onion Price (X3), and Padang City Per capita Income (X4). The analysis shows that the price of large red chili, curly red chili, the price of red onion has a positive and significant effect on the demand for large red chili in the city of Padang, but the income per capita in Padang does not have an influence on the demand for large red chili in the city of Padang.
\end{abstract}

Keywords: big red chili, red onion, demand, price

\section{PENDAHULUAN}

Sektor pertanian mempunyai peranan yang sangat penting bagi perekonomian Indonesia. Peranan pertanian antara lain adalah (1) sektor pertanian menyumbang sekitar 22,3\% dari Produk Domestik Bruto
(PDB), (2) sektor pertanian mampu menyediakan sekitar 54\% dari angkatan kerja yang ada, dan bahkan di provinsi tertentu kontribusinya melebihi angka tersebut, (3) sektor pertanian mampu menyediakan keragaman menu pangan dan karenanya sektor pertanian sangat 
mempengaruhi konsumsi dan gizi masyarakat, (4) sektor pertanian mampu mendukung sektor industri, baik industri hulu maupun industri hilir, (5) ekspor hasil pertanian yang semakin meningkat menyumbang devisa yang semakin besar (Yasrizal dan Hasan, 2016; Widyawati, 2017; Hayati, Elfiana, Martina, 2017)

Salah satu subsektor pertanian yang dikembangkan di Indonesia adalah tanaman hortikultura (Ilsan et al., 2016; Tirani, Pranoto dan Moelyo, 2018). Tanaman hortikultura merupakan salah satu tanaman yang menunjang pemenuhan gizi mayarakat sebagai sumber vitamin, mineral, protein, dan karbohidrat (Pitaloka, 2017). Hortikultura merupakan salah satu subsektor pertanian yang memberikan kontribusi yang cukup tinggi bagi perekonomian nasional. Salah satu produk dari holtikultura adalah cabai (Capsicum annum varlongum). Cabai merupakan salah satu komoditas hortikultura yang memliki nilai ekonomi penting di Indonesia (Tsurayya dan Kartika, 2015; Sondakh dan Rengku, 2017). Cabai merupakan tanaman perdu dari famili terong-terongan yang memiliki nama ilmiah Capsicum sp. Cabai berasal dari benua Amerika tepatnya daerah Peru dan menyebar ke negara- negara benua Amerika, Eropa, Asia termasuk negara Indonesia (Alex, 2011)

Berdasarkan dari hasil survey Pusat Kajian Sosial Budaya dan Ekonomi (PKSBE) menghitung kebutuhan cabai warga kota Padang mencapai 36,91 ton per hari. Sedangkan produksi cabai merah di Indonesia tahun 2005 hingga 2009 fluktuatif. Berbeda dari kecendrungan nasional, produksi cabai merah di Sumatera Barat dari tahun 2005 hingga 2009 mengalami kenaikan. Meningkatnya permintaan cabai tidak diiringi dengan peningkatan produksi menjadi salah satu penyebab kenaikan harga cabai.

Dengan demikian berdasarkan latar belakang, maka diperlukan suatu penelitian untuk menganalisis permasalahan tersebut. Penelitian ini bertujuan untuk menganalisis Permintaan Cabai Merah Besar di Kota
Padang. Adapun cakupan wilayah dalam penelitian ini adalah Kota Padang yang mana Kota Padang merupakan Ibukota dan menjadi kota terbesar di Provinsi Sumatera Barat, yang mana variabel bebas dalam penelitian ini adalah Harga Cabai Merah Besar, Harga Cabai Merah Keriting, Harga Bawang Merah dan Pendapatan Perkapita di Kota Padang. Sedangkan Variabel terikat dalam penelitian ini adalah Permintaan Cabai Merah Besar di Kota Padang.

\section{LITERATURE REVIEW}

\section{Teori Permintaan}

Menurut (Sudarman, 2000), ada empat faktor yang mempengaruhi permintaan terhadap komoditi tertentu pada suatu daerah. Empat faktor tersebut adalah :

a. Harga barang itu sendiri

Sesuai dengan hukum permintaan, maka jumlah barang yang diminta akan berubah secara berlawanan dengan perubahan harga.

b. Harga barang-barang lain yang ada kaitannya dalam penggunaan barangbarang konsumsi pada umumnya mempunyai kaitan penggunaan antara yang satu dengan yang lain. Kaitan penggunaan antara kedua barang konsumsi pada dasarnya dapat dibedakan menjadi dua macam yaitu saling mengganti (substituted relation) dan saling melengkapi (complementary relation).

c. Penghasilan (dalam arti uang konsumen). Ini merupakan faktor penentu yang penting dalam permintaan suatu barang. Pada umumya semakin besar penghasilan seseorang maka semakin besar pula permintaan seseorang terhadap suatu barang, demikian sebaliknya.

d. Jumlah konsumen. Jumlah konsumen sangat mempengaruhi jumlah permintaan terhadap suatu barang, semakin banyak jumlah konsumen, maka semakin banyak pula permintaan konsumen terhadap suatu barang demikian pula sebaliknya. 


\section{Kurva Permintaan}

Ada dua macam kurva permintaan yang dapat diturunkan, yaitu apa yang disebut ordinary demand curve dan compensated demand curve. Ordinary demand curveadalah kurva permintaan yang menghubungkan perubahan harga dengan perubahan jumlah barang total (baik efek substitusi maupun efek pendapatan). Sedangkan compensated demand curveadalah kurva permintaan yang menghubungkan perubahan harga dengan perubahan jumlah barang akibat efek substitusi saja. Kemiringan (slope) dari suatu kurva permintaan menggambarkan besarnya perubahan jumlah barang yang diminta sebagai akibat perubahan harga. Semakin landai suatu kurva permintaan semakin besar perubahan jumlah barang yang diminta jika harga naik atau turun.

Ukuran yang dapat digunakan untuk mengetahui hubungan antara permintaan dengan faktor yang mempengaruhinya ialah elastisitas permintaan. Elastisitas permintaan dapat dibedakan menjadi tiga macam, yaitu :

\section{Elastisitas Harga}

Menurut (Sudarman, 2000) elastisitas harga adalah tingkat kepekaan relatif dari jumlah yang diminta konsumen, akibat adanya perubahan harga barang. Dengan kata lain elastisitas harga adalah perubahan proporsional dari sejumlah barang yang diminta dibagi dengan perubahan proporsional dari harga. Ukuran elastisitas yang paling luas dipergunakan adalah elastisitas harga dari permintaan, yang mengukur daya tanggap jumlah yang diminta terhadap perubahan dalam harga produk, dengan mempertahankan nilai semua variabel lainnya dalam fungsi permintaan konstan dengan menggunakan rumus elastisitas titik, elastisitas harga dari permintaan ditemukan sebagai berikut :

$E P=\frac{\text { Persentase perubahan dlm jumlah }(Q)}{\text { Persentase perubahan dlm harga }(P)}$

\section{Elastisitas Pendapatan}

Koefisien yang menunjukkan sampai dimana besarnya perubahan permintaan terhadap sesuatu barang sebagai akibat daripada suatu perubahan pendapatan pembeli dinamakan elastisitas permintaan pendapatan atau secara ringkas elastisitas pendapatan. Untuk kebanyakan barang kenaikan pendapatan akan menyebabkan kenaikan permintaan. Disini terdapat hubungan yang searah diantara perubahan pendapatan dan perubahan permintaan, dengan demikian elastisitas pendapatannya adalah positif. Barang-barang yang elastisitas pendapatannya adalah demikian dinamakan barang normal. Beberapa jenis barang mengalami pengurangan dalam jumlah yang dibeli apabila pendapatan bertambah, berarti perubahan pendapatan dan jumlah yang dibeli bergerak ke arah yang berkebalikan, dengan demikian elastisitasnya negatif. Barang seperti ini dinamakan barang inferior (Sukirno, 2006)

Berdasarkan besarnya elastisitas pendapatan, komoditi dapat diklasifikasikan menjadi dua jenis, yaitu kebutuhan pokok (necessities) dan luks (luxuries). Bila elastisitas pendapatan sangat kecil (lebih kecil dari satu), maka jumlah barang yang diminta konsumen tidak responsif terhadap adanya perubahan pendapatan. Tingkat konsumsi tidak begitu jauh berbeda pada berbagai tingkat pendapatan. Komoditi dengan elastisitas pendapatan kecil seperti ini disebut barang kebutuhan pokok. Di lain pihak komoditi yang mempunyai elastisitas besar dari satu, maka diklasifikasikan sebagai barang luks (Sudarman, 2000).

Elastisitas pendapatan dari permintaan mengukur daya tanggap permintaan terhadap perubahan dalam pendapatan, dengan mempertahankan pengaruh semua variabel lainnya tetap konstan. Membiarkan I untuk mewakili pendapatan, elastisitas titik dalam pendapatan didefinisikan sebagai berikut : 
EI $\frac{\text { Persentase perubahan dalam jumlah }(Q)}{\text { Persentase perubahan dalam pendapatan }(I)}$

Pendapatan dan jumlah yang dibeli umumnya bergerak dalam arah yang sama, yaitu pendapatan dan penjualan berkaitan secara langsung dan bukan secara terbalik (Pappas \& Hirschey, 1995).

\section{Elastisitas Silang}

Koefisien yang menunjukkan sampai dimana besarnya perubahan permintaan terhadap sesuatu barang apabila terjadi perubahan terhadap harga barang lain dinamakan elastisitas permintaan silang atau dengan ringkas elastisitas silang. Apabila perubahan harga barang $\mathrm{Y}$ menyebabkan permintaan barang $\mathrm{X}$ berubah, maka sifat perhubungan diantara keduanya digambarkan oleh elastisitas silang (Sukirno, 2006). Konsep elastisitas harga silang dipergunakan untuk meneliti daya tanggap permintaan akan satu produk terhadap perubahan dalam harga produk lainnya. Elastisitas harga silang diketahui dengan permintaan berikut ini:

$E S=\frac{\text { Persentase perubahan dalam jumlah } X}{\text { Persentase perubahan dalam jumlah } Y}$

Dimana $\mathrm{Y}$ dan $\mathrm{X}$ adalah dua produk yang berbeda. Elastisitas harga silang untuk pengganti selalu positif, harga satu barang dan permintaan akan barang lainnya selalu bergerak dalam arah yang sama. Elastisitas harga silang adalah negatif untuk pelengkap, harga dan jumlah bergerak dalam arah yang berlawanan. Yang terakhir, elastisitas harga silang nol, atau dekat dengan nol, untuk barang-barang yang tidak berkaitan, variasi dalam harga satu barang tidak berpengaruh terhadap permintaan akan barang kedua (Pappas \& Hirschey, 1995)

Pengukuran elastisitas silang antara dua jenis barang diperlukan untuk melihat tingkat hubungan antara keduanya, baik hubungan yang bersifat saling melengkapi atau hubungan yang saling dapat mengganti. Semakin tinggi elastisitas silang, maka semakin tinggi (erat) pula tingkat hubungan saling mengganti atau saling melengkapi antara keduanya (Sudarman, 2000).

\section{METODE PENELITIAN}

\section{Jenis Penelitian}

Penelitian ini digolongkan dalam penelitian deskriptif analitis. Penelitian deskriptif adalah suatu jenis penelitian yang terdapat pengumpulan data, mencari berbagai informasi yang bertujuan untuk menguji hipotesis dari suatu permasalahan yang ada. Sedangkan penelitian analitis berarti data yang dikumpulkan mula-mula disusun, dijelaskan, dan kemudian di analitis. Jenis penelitian ini ditunjukkan untuk mengetahui bagaimana Permintaan Cabai Merah Besar di Kota Padang.

\section{Model Penelitian}

Model yang digunakan dalam penelitian ini merujuk kepada model yang pernah digunakan dalam penelitian sebelumnya oleh Tria Rosana Dewi (2009) dengan persamaan sebagai berikut :

$$
\begin{aligned}
\text { Ln Qdt }= & \ln b 0+b 1 \ln X 1+b 2 \ln X 2+b 3 \ln X 3 \\
& +b 4 \ln X 4+b 5 \ln X 5+e
\end{aligned}
$$

Namun, penelitian ini sedikit memiliki perbedaan persamaan yakni :

$$
\begin{aligned}
Y d= & \alpha+b 1 X 1+b 2 X 2+b 3 X 3+b 4 X 4+ \\
& b 5 X 5+e
\end{aligned}
$$

Dimana :

$$
\begin{aligned}
\text { Yd } & =\text { Jumlah konsumsi cabai merah } \\
& \text { besar }(\mathrm{Kg} / \mathrm{bln}) \\
\alpha & =\text { Konstanta } \\
\mathrm{b} 1, . \mathrm{b} 5= & \text { Koefisien Regresi } \\
\mathrm{X} 1 & =\text { Harga Cabai Merah Besar } \\
\mathrm{X} 2 & =\text { Harga Cabai Merah Keriting } \\
\mathrm{X} 3 & =\text { Harga Bawang Merah } \\
\mathrm{X} 4 & =\text { Jumlah Penduduk Kota Padang } \\
\mathrm{X} 5 & =\text { Pendapatan Perkapita Kota Padang } \\
\mathrm{e} & =\text { Erorr }
\end{aligned}
$$




\section{HASIL DAN PEMBAHASAN}

\section{Hasil Koefisien Determinasi $\left(\mathbf{R}^{2}\right)$}

Nilai koefisien determinasi menunjukkan seberapa besar sumbangan variabel - variabel bebas secara bersamasama terhadap variabel terikat atau tidak bebasnya. Pada tabel model summary, nilai $R^{2}$ sebesar 0,952. Hal ini menunjukkan bahwa kemampuan faktor daya beli yang terdiri dari harga cabai merah besar ditingkat konsumen, harga cabe merah keriting ditingkat konsumen, harga bawang merah ditingkat konsumen dan pendapatan perkapita dalam menjelaskan variabel permintaan cabe sebesar 95,2\%, sedangkan $4,8 \%$ lagi sisanya dipengaruhi oleh variabel lain di luar variabel yang diteliti.

Berdasarkan analisis uji $\mathrm{F}$ yang dilakukan dapat diketahui bahwa signifikan sebesar 0,00. Hal ini menunjukkan bahwa variabel-variabel bebas yang diamati yaitu harga cabai merah besar ditingkat konsumen, harga cabai merah keriting ditingkat konsumen, harga bawang merah ditingkat konsumen dan jumlah pendapatan perkapita secara bersama - sama berpengaruh nyata terhadap permintaan cabe di Kota Padang.

Tabel 1.

Hasil Analisis Uji-t Masing - Masing Variabel Bebas Terhadap Permintaan Cabai di Kota Padang Tahun 2009-2018

\begin{tabular}{llll}
\multicolumn{4}{c}{ Padang Tahun 2009-2018 } \\
\hline Variabel & $\begin{array}{l}\text { Koef } \\
\text { Regresi }\end{array}$ & T Hit & Sig \\
\hline $\begin{array}{l}\text { Harga cabai merah } \\
\text { besar (X1) }\end{array}$ & 23,257 & 2,023 & 0,099 \\
$\begin{array}{l}\text { Harga cabai merah } \\
\text { keriting (X2) }\end{array}$ & 26,502 & 2,387 & 0,063 \\
$\begin{array}{l}\text { Harga bawang merah } \\
\text { (X3) }\end{array}$ & 51,763 & 3,933 & 0,01 \\
Pendapatan (X5) & 0,002 & 1,668 & 0,156 \\
\hline
\end{tabular}

\section{Hasil Uji T}

Uji - $\mathrm{t}$ digunakan untuk mengetahui pengaruh variabel bebas yang diteliti secara individual terhadap permintaan cabai di Kota Padang. Harga cabai merah besar, harga cabai merah keritiing dan harga bawang merah berpengaruh nyata terhadap permintaan cabai di Kota Padang pada tingkat kepercayaan 90\%. Hal ini ditunjukkan dengan oleh nilai probabilitas atau nilai signifikansi dari masing-masing variabel tersebut yang lebih kecil dari nilai a $=0,10(\mathrm{P}<0,10)$. Nilai signifikan cabai merah besar sebesar $0,099(<0,10)$, variabel cabai merah keriting dengan nilai signifikan sebesar 0,063 $(<0,10)$ dan variabel harga bawang merah dengan nilai signifikan sebesar $0,011(<0,10)$. Variabel pendapatan perkapita tidak berpengaruh secara nyata terhadap permintaan cabai di Kota Padang. Hal ini ditunjukkan dengan nilai signifikansi sebebsar 0,156 yang lebih besar dari pada 0,10 .

\section{Pembahasan}

Pengaruh dari variabel Harga Cabai Merah Besar terhadap Permintaan cabai Merah besar di Kota Padang menunjukkan nilai koefisien regresi adalah sebesar 23,257. Koefisien tersebut menunjukkan variabel Harga Cabai Merah Besar berpengaruh positif terhadap Permintaan Cabai Merah Besar di Kota Padang. Apabila terjadi kenaikan variabel Harga Cabai Merah Besar sebesar 1 persen, maka akan meningkatkan nilai variabel Permintaan Cabai Merah Besar sebesar 23,257 persen, dengan asumsi variabel lainnya tetap. Dan variabel Harga Cabai Merah Besar juga berpengaruh signifikan dengan nilai probability sebesar 0,099. Artinya, variabel Harga Cabai Merah Besar memiliki pengaruh yang positif dan signifikan terhadap permintaan Cabai Merah Besar di Kota Padang.

Pengaruh dari variabel Harga Cabai Merah Keriting terhadap Permintaan Cabai Merah Keriting di Kota Padang menunjukkan nilai koefisien regresi adalah sebesar 26,502. Koefisien tersebut menunjukkan variabel Harga Cabai Merah Keriting berpengaruh positif terhadap Permintaan Cabai Merah Keriting di Kota Padang. Apabila terjadi kenaikan variabel 
Harga Cabai Merah Keriting sebesar 1 persen, maka akan meningkatkan nilai variabel Permintaan Cabai Merah Keriting di Kota Padang sebesar 26,502 persen, dengan asumsi variabel lainnya tetap. Harga Cabai Merah Keriting juga berpengaruh signifikan dengan nilai probability sebesar 0,063. Artinya, variabel Harga Cabai Merah Keriting memiliki pengaruh yang positif dan signifikan terhadap permintaan Cabai Merah Keriting di Kota Padang.

Pengaruh dari variabel Harga Bawang Merah terhadap Permintaan Bawang Merah di Kota Padang menunjukkan nilai koefisien regresi adalah sebesar 51,763. Koefisien tersebut menunjukkan variabel Harga Bawang Merah berpengaruh positif terhadap Permintaan Bawang Merah di Kota Padang. Apabila terjadi kenaikan variabel Harga Bawang Merah sebesar 1 persen, maka akan meningkatkan nilai variabel Permintaan Bawang merah di Kota Padang sebesar 51,763 persen, dengan asumsi variabel lainnya tetap. Harga Bawang Merah juga berpengaruh signifikan dengan nilai probability sebesar 0,011. Artinya, variabel Harga Bawang Merah memiliki pengaruh yang positif dan signifikan terhadap Permintaan Bawang Merah di Kota Padang.

Namun untuk variabel Pendapatan Perkapita Kota Padang, berdasarkan hasil pengujian diketahui hasil nilai signifikansi dari variabel Pedapatan Perkapita sebesar 0,002 yang mana hasil tersebut lebih besar dari nilai signifikansi sebesar 0,156 . Yang artinya bahwa variabel Pendapatan Perkapita Kota Padang tidak memiliki pengaruh yang signifikan terhadap Permintaan Cabai Merah Besar di Kota Padang.

\section{SIMPULAN}

Permintaan cabai secara serempak dipengaruhi oleh faktor harga cabai merah besar ditingkat konsumen, harga cabai merah keriting ditingkat konsumen, harga bawang merah ditingkat konsumen dan pendapatan perkapita. Namun secara parsial permintaan cabai dipengaruhi secara nyata oleh faktor harga cabai merah besar ditingkat konsumen, harga cabai merah keriting ditingkat konsumen dan harga bawang merah ditingkat konsumen, dengan korelasi yang paling tinggi adalah variabel harga cabai merah besar ditingkat konsumen dan variabel harga cabai merah keriting ditingkat konsumen.

Elastisitas Harga cabai merah besar bersifat inelastis, yaitu persentase perubahan jumlah cabai lebih kecil daripada persentase perubahan harga. Elastisitas Harga cabai merah keriting juga bersifat inelastis. Yangmana harga cabai merah keriting lebih tinggi daripada cabai merah besar, dikarenakan konsumen harganya relative lebih murah daripada harga cabai merah besar. Elastisitas harga bawang merah juga bersifat inelastis, yaitu memiliki nilai positif yang menunjukkan bahwa bawang merah merupakan barang komplementer dari cabai merah besar. Permintaan cabai bersifat inelastic terhadap perubahan pendapatan perkapita dikarenakan penduduk di Kota Padang belum mampu memenuhi kebutuhan pokok lainnya.

\section{DAFTAR PUSTAKA}

Alex, S. (2011). Usaha Tani Cabai: Kiat Jitu Bertanam Cabai di Segala Musim.Merah di Enam Kota Besar di Jawa-Bali (Kasus Pengendalian Harga Cabai Merah.

Hayati, M., Elfiana dan Martina. (2017). Peranan sektor pertanian dalam pembangunan wilayah Kabupaten Bireuen Provinsi Aceh. Jurnal S. Pertanian, 1 (3) : 213 -222.

Ilsan, M. Nugroho, A.D. Efrinda. Winaryo. Handoyo, R. Suparmono dan Puspitasari, R. (2016). Agribisnis tanaman hortikultura di Kabupaten Cilacap Provinsi Jawa Tengah. Agro Ekonomi, 27 (2): 233-252.

Pappas, J. L., \& Hirschey, M. (1995). Ekonomi Managerial Jilid 1. Jakarta: Binarupa Aksara. 
Pitaloka, D. (2017). Hortikultura: Potensi, Pengembangan dan Tantangan. Jurnal Teknologi Terapan, 1(1):1-4.

Sondakh, N dan Rengku, J.O. (2017). Faktor-Faktor Yang Memengaruhi Peningkatan Pendapatan Usahatani Cabai Rawit di Kabupaten Minahasa Selatan. Jurnal Bisnis dan Kewirausahaan, 13(2): 74-86.I

Sudarman, A. (2000). Teori Ekonomi Mirko: Buku I. Yogyakarta: BPSE.

Sukirno, S. (2006). Mikro Ekonomi (Edisi Ketiga). Jakarta: PT Raja Grafindo.

Tirani. Pranoto, Y.S. Moelyo, H. (2018). Kontribusi Sektor Pertanian berdasarkan Keunggulan Wilayah di Kabupaten Bangka. Caraka Tani:
Journal of Sustainable Agriculture, 33(1): 42-49.

Tsurayya, S. Dan Kartika, L. (2015). Kelembagaan dan Strategi Peningkatan Daya Saing Komoditas Cabai Kabupaten Garut. Jurnal Manajemen \& Agribisnis, 12(1): 1-13.

Widyawati, R.F. (2017). Analisis keterkaitan sektor pertanian dan pengaruhnya terhadap perekonomian Indonesia (analisis input ouput). Jurnal Economia, 13(1): 14-27.

Yasrizal dan Hasan, Ishak. (2016). Pengaruh Pembangunan Sektor Pertanian Terhadap Distribusi Pendapatan dan Kesempatan Kerja Di Indonesia. JIEP, 16 (1):54-64. 